Research Article

\title{
Fuzzy Logic to Assess the Conformity of Work in Small Enterprises of Traditional Medicines
}

\author{
Eliza Dwinta $^{1^{*}}$, Ajie Kusuma Wardhana ${ }^{2}$, Baniady Gennody Pronosokodewo ${ }^{3}$, \\ Raden Jaka Sarwadhamana ${ }^{4}$
}

1 Department of Pharmacy, Faculty of Health Science, Universitas Alma Ata, Jalan Brawijawa

No.99 Bantul, Daerah Istimewa Yogyakarta, Indonesia 55183

2 Department of Electrical and Information Technology, Universitas Gadjah Mada, Jalan Grafika No.2 Yogyakarta, Daerah Istimewa Yogyakarta, Indonesia 55281

3 Department of Accounting, Faculty of Business, Universitas PGRI Yogyakarta, Jalan IKIP PGRI I Sonosewu No.117 Bantul, Daerah Istimewa Yogyakarta 55182

4 Department of Hospital Administration, Faculty of Health Science, Universitas Alma Ata, Jalan Brawijawa No.99 Bantul, Daerah Istimewa Yogyakarta, Indonesia 55183

* Corresponding author: elizadwinta@almaata.ac.id

Received: 20 July 2020; Accepted: 20 November 2020; Published: 15 December 2020

\begin{abstract}
Good Manufacturing Practices for Traditional Medicine (CPOTB) certification given by National Food and Drug Agency (BPOM) to Small Enterprises of Traditional Medicines (UKOT) is a claim from the production process of traditional medicines that is in accordance with CPOTB. However, not all human resources at UKOT understand and apply existing guidelines in the work practices of traditional medicine production. This study aims to assess the conformity of work by calculating the gap between knowledge of work practices in human resources in one UKOT Yogyakarta with fuzzy method. This assessment is a quantitative, cross-sectional study using a questionnaire that was adapted and modified from six categories of cause and effect. Respondents included in this study were all human resources in UKOT as many as 24 people (total sampling). The results obtained from the gap calculation of work conformity based on the six categories are machinery that have positive values $(0,1146)$. Human resources who work at UKOT have a good understanding of the CPOTB and are already good at implementing work practices in accordance with the CPOTB in the machinery category. The findings that personnel pass through the production area, storage area and quality control area, as well as analysis methods that have not been validated periodically, can be used as an ingredient for improvement by implementing corrective-action-preventive-action on order to improve the quality of work in accordance with CPOTB and guarantee the quality of traditional medicine products from the UKOT Yogyakarta.
\end{abstract}

Keywords: CPOTB, Work conformity, Work practice, UKOT

\section{Introduction}

Traditional medicine has been circulating and is widely consumed by the people of Indonesia. Traditional medicines consumed by the community must be produced in accordance with safety standards to ensure the quality of the drugs produced. Safety standards in the process of producing traditional medicines are listed in Good Manufacturing Practices for Traditional Medicine (CPOTB) which are used as guidelines to ensure product quality. Requirements in the CPOTB must be fulfilled to protect the public from the use of traditional medicines that do not fulfilled quality standards [1]. These requirements include: personnel; buildings, facilities and equipment; sanitation and hygiene; documentation; production; quality control; contract manufacturing and analysis; good storage and delivery of traditional medicines; handling complaints against products, product recalls and product returns; and self-introspection [2].

Small Enterprises of Traditional Medicines (UKOT) employs pharmacists as the person in charge [3]. This pharmacist will be responsible for all traditional medicine production activities in accordance with CPOTB to maintain the quality of traditional medicine products. Human resources working at UKOT have 
different levels of education and must undergo special training to be able to work in the field of traditional medicine production so that the quality of traditional medicines can be maintained. Human resources working at UKOT are aware of the CPOTB guidelines. Work conformity for CPOTB is assessed from the implementation of CPOTB certification by National Food and Drug Agency (BPOM). This study aims to determine the conformity of work as seen from the gap between the knowledge possessed by human resources with the work practices of СРОТВ. The gap assessment is calculated by the fuzzy method.

Fuzzy set theory is conceptual mathematics to create models of processes that are agreed upon by multidimensional, subjectivity, and renewal. Rating to make an application based on optimization, that is well utilization and service ability. Fuzzy logic as a decision-making tool is used in many disciplines [4]. Fuzzy logic has been approved successfully agreed to offer rougher modelling approach $[5,6]$. Therefore, the fuzzy logic will be used to calculate linguistic variables in the questionnaire which will assess the kowledge and realities of work practice for CPOTB into unbiased model according to fuzzy logic capabilities to express gradual transitions. Fuzzy logic able to transform a membership into nonmembership function. The membership function is a representation of uncertainty measurement such as the perception of one's understanding of CPOTB [7].

\section{Methods}

\section{Research subject}

The population in this study were employees at one of the UKOT in Yogyakarta related to traditional medicine production $(\mathrm{N}=24)$. The sampling technique used was total sampling, so that the respondents included in this study were all employees related to production, starting from the operator, research and development, and the head of division $(\mathrm{n}=24)$.

\section{Questionnaire design}

Research on work conformity in UKOT Yogyakarta was a kind of experimental research with a quantitative approach. This is a cross-sectional study, which used to find out the gap between a work conformity in the actual situation and the knowledge of work regulation in Small Enterprises of Traditional Medicines.

The questionnaire was developed from a brief interview with the Head of Quality Assurance. Study literature was also conducted to determine the design of the questionnaire. The results of the search for questionnaire designs in the literature study are the six important dimensions in the pharmaceutical industry, specifically manpower, machinery, milieu, material, method, and measurement [8]. We use those important dimensions and formulated with some modification according to the main aspects of CPOTB. Validation of the questionnaire is done by the academics and skillful persons $(n=3)$ who were working in the traditional industry. They judged about correction and efficiency of the questionnaire. The final study instrument used in this study is a self-administered questionnaire contains 60 ratio scale (1-2) statements about the practical and knowledge of work regulation on CPOTB.

\section{Fuzzy method}

Fuzzy is one of a kind of function that was meant to representing uncertainty and as a tool to create an unbiased model. The uncertainty and the disadvantages about the information involving several particular elements problem [9]. In this subsequent discuss the basic arithmetic of fuzzy numbers which interpreted as follows. Let $A_{1}=\left(c_{1}, b_{1}, a_{1}\right)$ and $A_{2}=\left(c_{2}, b_{2}, a_{2}\right)$ are triangular fuzzy number $[10,11]$.

- Addition Operation $\left(A_{1}\right.$ and $\left.A_{2}\right)$ (Equation 1)

$$
A_{1}+A_{2}=\left(a_{1}+a_{2}, b_{1}+b_{2}, c_{1}+c_{2}\right)
$$

- Subtraction Operation $\left(A_{1}\right.$ and $\left.A_{2}\right)$ (Equation 2)

$$
A_{1}-A_{2}=\left(a_{1}-c_{2}, b_{1}-b_{2}, c_{1}+a_{2}\right)
$$

- Devision Operation ( $\mathrm{r}$ is real number) (Equation 3) 


\section{Linguistic variables}

$$
\frac{A_{1}}{r}=\left(\frac{a_{1}}{r}, \frac{b_{1}}{r}, \frac{c_{1}}{r}\right)
$$

To calculate the quantitative analysis we should convert the linguistic variables into triangular fuzzy numbers. The perception scores from the questionnaire was 1 for "Low", 1.5 for "Mid", and 2 for "High". The conversion is shown as Table 1 and the fuzzy set is shown in Figure 1 [10]. The membership function is the respresentation of linguistic variables in form of numbers. Thus, the representation numbers will be used to perform calculation on gap score later on [7]. Linguistic variables knowledge is representating for repondend knowledge, meanwhile the Linguistic variables practice is representating workers practice point.

Table 1. Linguistic Variables of Questionnaire

\begin{tabular}{ccccc}
\hline Scale Relative & $\begin{array}{c}\text { Linguistic Variables } \\
\text { Knowledge }\end{array}$ & $\begin{array}{c}\text { Membership } \\
\text { Function }\end{array}$ & $\begin{array}{c}\text { Linguistic Variables } \\
\text { Practice }\end{array}$ & $\begin{array}{c}\text { Membership } \\
\text { Function }\end{array}$ \\
\hline 1 & Low $(a)$ & $(0,1)$ & Low $(a)$ & $(0,1)$ \\
2 & Mid $(b)$ & $(1,1.5)$ & Mid $(b)$ & $(1,1.5)$ \\
3 & High $(c)$ & $(1.5,2)$ & High $(c)$ & $(1.5,2)$ \\
\hline
\end{tabular}

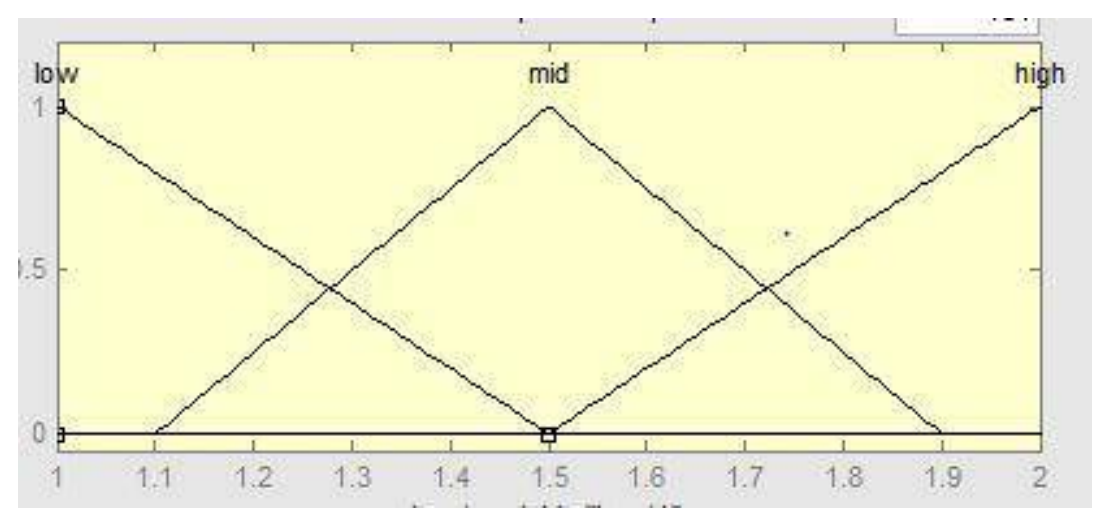

Figure 1. Fuzzy Set Graphic from a perception score

\section{Total score calculation}

To calculate the score value we interpret the expected or in this particular case knowledge value as $A_{\text {ein }}$ from $n^{\text {th }}$ interviewee based on questioner item interpreted by $i$. As for $A_{\text {pin }}$ is the interpretation of practical value from $n^{\text {th }}$. Additionally, the $T A_{e i}$ is the interpretation of total service quality, meanwhile $T A_{p i}$ is interpreting every interviewee total service quality. The equation is shown as follows [10].

$$
T A_{e i}=\sum_{1}^{n} A_{\text {ein }} ; T A_{p i}=\sum_{1}^{n} A_{\text {pin }}
$$

By using the equation above, the total amount of knowledge and practical value will be calculated from item $i$ which interpreted the questioner items [10].

\section{Calculating the mean score}

To calculate the mean score (defuzzification) to produce a representative single value we used the equation below.

$$
M A_{e i}=\frac{T A_{e i}}{N} ; M A_{p i}=\frac{T A_{p i}}{N}
$$

Let $M A_{e i}$ is the calculation of knowledge expected from the average service quality, while $M A_{p i}$ is to calculate the practical average service quality from interview item $i$.

\section{Calculating the gap}

After calculating the mean score, it is necessary to measure the gap of the fuzzy value to determine which of the interviewee respond has the smallest gap value. In order to calculate the gap value we use the equation below [10].

$$
\text { Gap }=M A_{p i} \ominus M A_{e i}
$$




\section{Results and Discussions}

Data obtained from 24 respondents with criteria 22 male (91.7\%) and 2 female (8.3\%) with the most age being $20-25$ years as many as 15 people (62.5\%). The last education obtained by 17 respondents $(70.8 \%)$ was high school. The distribution of respondents' work areas in traditional medicine productions was 10 people $(41.7 \%)$ working in the production department, 6 people $(25 \%)$ working in the procurement and logistics department, 5 people $(20.8 \%)$ working in the laboratory/quality control, and 3 people $(12.5 \%)$ working in the manufacturing and operation department.

The dimensions assessed in this work conformity analysis are based on "cause and effect diagram (6M)", namely the "Manpower" category that describes human resources and organizational structures in UKOT, "Machinery" category regarding equipment and technology available in UKOT, "Milieu" category about buildings and the UKOT environment, "Material" category regarding active pharmaceutical substances and finished products, the "Method" category and finally the "Measurement" of self-inspection, validation, qualification and analytical methods used to guarantee the quality of traditional medicinal products [8].

The formula of fuzzification which $b_{i}$ is the average of fuzzy set at any level, and $n$ is the summary of respondent as follows

$$
\begin{gathered}
\text { Low value }=\frac{b_{i l^{*}} n_{1}+b_{i l^{*}} n_{2}+b_{i l^{*}} n_{3}+\ldots+b_{i(k-l)^{*}} n_{k}}{n_{1}+n_{2}+n_{3}+\ldots+n_{k}} \\
\text { Mid value }=\frac{b_{i l^{*} n_{1}+b_{i l} * n_{2}+b_{i l} l_{3}+\ldots+b_{i k^{*}} n_{k}}}{n_{1}+n_{2}+n_{3}+\ldots+n_{k}} \\
\text { High value }=\frac{b_{i l^{*}} n_{1}+b_{i l^{*}} n_{2}+b_{i l} * n_{3}+\ldots+b_{i k^{*}} n_{i(k-1)}+b_{i k^{*}} n_{k}}{n_{1}+n_{2}+n_{3}+\ldots+n_{k}}
\end{gathered}
$$

The calculation of practical and knowledge the respondents, we used defuzzification to produce a representative single value (Table $2,3,4,5,6,7$ ).

It has been shown in Table 2 that the fourth and tenth questions have a positive gap, which means that the work practices carried out by human resources in UKOT Yogyakarta in accordance with the guidelines stated in CPOTB achieved high scores. The questions include "Each personnel is not burdened with excessive responsibility to avoid risks to the quality of traditional medicine". This can support personnel productivity because the workload is in accordance with the capabilities they have. And "Visitors or personnel who did not receive special training are not allowed to enter the production area and laboratory", to prevent exposure to contaminants from personnel who do not understand work procedures in the production area and laboratories. A high score indicates that all human resources in UKOT Yogyakarta comply with these guidelines.

Based on human resource theory, a number of studies believe that human resources are the most important asset in a company. In the pharmaceutical industry, human resources have an important role in carrying out knowledge-based work practices to gain a competitive advantage by creating new idea, solving problems, and making decisions [12]. The pharmaceutical industry is very dependent on service, performance, and employee productivity [13]. Human resource practices encourage the application of rules and procedures to make decisions based on capabilities. The practice is supported by the feeling of those who believe that the training they undergo in developing work knowledge and skills is of high quality and will be related to their professional success [14].

On the machinery dimension, positive gaps include questions regarding the clear marking of equipment identity, written procedures for maintaining equipment, easy access to sources of water, steam, and pressurized air or vacuum, marking the direction of water and airflow, and recording the order of use of main equipment and the area where the product is processed in the logbook (Table 3). The positive gap in this dimension means that all personnel is very good at carrying out work practices in accordance with the guidelines in the CPOTB aspects of "Buildings, facilities, and equipment" [2]. 
E-ISSN: 2720-9326

Table 2. Manpower fuzzification

\begin{tabular}{|c|c|c|c|c|c|c|c|c|c|c|c|}
\hline \multirow{3}{*}{ Question } & \multicolumn{2}{|c|}{ Recap score } & \multicolumn{6}{|c|}{ Fuzzification } & \multirow{2}{*}{\multicolumn{3}{|c|}{ Defuzzification }} \\
\hline & \multirow{2}{*}{ Knowledge } & \multirow{2}{*}{ Practical } & \multicolumn{3}{|c|}{ Knowledge } & \multicolumn{3}{|c|}{ Practical } & & & \\
\hline & & & Low & Mid & High & Low & Mid & High & Knowledge & Practical & Gap \\
\hline Q1 & 23 & 24 & 1,9583 & 2,9375 & 3,9167 & 2,0000 & 3,0000 & 4,0000 & 3,4271 & 3,5000 & $-0,0729$ \\
\hline $\mathrm{Q} 2$ & 22 & 22 & 1,9167 & 2,8750 & 3,8333 & 1,9167 & 2,8750 & 3,8333 & 3,3542 & 3,3542 & $0 *$ \\
\hline Q3 & 20 & 20 & 1,8333 & 2,7500 & 3,6667 & 1,8333 & 2,7500 & 3,6667 & 3,2083 & 3,2083 & $0 *$ \\
\hline Q4 & 22 & 20 & 1,9167 & 2,8750 & 3,8333 & 1,8333 & 2,7500 & 3,6667 & 3,3542 & 3,2083 & $0,1458^{* *}$ \\
\hline Q5 & 22 & 22 & 1,9167 & 2,8750 & 3,8333 & 1,9167 & 2,8750 & 3,8333 & 3,3542 & 3,3542 & $0 *$ \\
\hline Q6 & 10 & 15 & 1,4167 & 2,1250 & 2,8333 & 1,6250 & 2,4375 & 3,2500 & 2,4792 & 2,8437 & $-0,3646$ \\
\hline Q7 & 23 & 23 & 1,9583 & 2,9375 & 3,9167 & 1,9583 & 2,9375 & 3,9167 & 3,4271 & 3,4271 & $0 *$ \\
\hline Q8 & 24 & 24 & 2,0000 & 3,0000 & 4,0000 & 2,0000 & 3,0000 & 4,0000 & 3,5000 & 3,5000 & $0^{*}$ \\
\hline Q9 & 6 & 17 & 1,2917 & 1,9375 & 2,5833 & 1,7083 & 2,5625 & 3,4167 & 2,2604 & 2,9896 & $-0,7292$ \\
\hline Q10 & 13 & 12 & 1,5417 & 2,3125 & 3,0833 & 1,5000 & 2,2500 & 3,0000 & 2,6979 & 2,6250 & $0,0729 * *$ \\
\hline
\end{tabular}

Notes: *The value of work practices is the same as the value of knowledge, ${ }^{* *}$ The value of work practice is higher than the value of knowledge

Table 3. Machinery fuzzification

\begin{tabular}{|c|c|c|c|c|c|c|c|c|c|c|c|}
\hline \multirow{3}{*}{ Question } & \multicolumn{2}{|c|}{ Recap score } & \multicolumn{6}{|c|}{ Fuzzification } & \multirow{2}{*}{\multicolumn{3}{|c|}{ Defuzzification }} \\
\hline & \multirow{2}{*}{$\begin{array}{c}\text { Knowledg } \\
\mathrm{e}\end{array}$} & \multirow{2}{*}{ Practical } & \multicolumn{3}{|c|}{ Knowledge } & \multicolumn{3}{|c|}{ Practical } & & & \\
\hline & & & Low & Mid & High & Low & Mid & High & Knowledge & Practical & Gap \\
\hline Q11 & 23 & 23 & 1,9583 & 2,9375 & 3,9167 & 2,0000 & 3,0000 & 4,0000 & 3,4271 & 3,4271 & $0^{*}$ \\
\hline Q12 & 24 & 24 & 1,9167 & 2,8750 & 3,8333 & 1,9167 & 2,8750 & 3,8333 & 3,5000 & 3,5000 & $0^{*}$ \\
\hline Q13 & 21 & 18 & 1,8333 & 2,7500 & 3,6667 & 1,8333 & 2,7500 & 3,6667 & 3,2812 & 3,0625 & 0,2187 ** \\
\hline Q14 & 7 & 15 & 1,9167 & 2,8750 & 3,8333 & 1,8333 & 2,7500 & 3,6667 & 2,2604 & 2,8437 & $-0,5833$ \\
\hline Q15 & 24 & 22 & 1,9167 & 2,8750 & 3,8333 & 1,9167 & 2,8750 & 3,8333 & 3,500 & 3,3542 & $0,1458^{* *}$ \\
\hline Q16 & 23 & 21 & 1,4167 & 2,1250 & 2,8333 & 1,6250 & 2,4375 & 3,2500 & 3,4271 & 3,2812 & $0,1458^{* *}$ \\
\hline Q17 & 23 & 22 & 1,9583 & 2,9375 & 3,9167 & 1,9583 & 2,9375 & 3,9167 & 3,4271 & 2,8750 & $0,5521^{* *}$ \\
\hline Q18 & 7 & 16 & 2,0000 & 3,0000 & 4,0000 & 2,0000 & 3,0000 & 4,0000 & 2,2604 & 2,9167 & $-0,6562$ \\
\hline Q19 & 22 & 18 & 1,2917 & 1,9375 & 2,5833 & 1,7083 & 2,5625 & 3,4167 & 3,3542 & 3,0625 & 0,2917 ** \\
\hline
\end{tabular}

Notes: ${ }^{*}$ The value of work practices is the same as the value of knowledge, ${ }^{*}$ The value of work practice is higher than the value of knowledge 
Table 4 illustrates the milieu dimension, and the question that shows a positive gap is the question of spatial design created by ensuring compatibility with other production activities that may be carried out in the same or adjoining facilities, closing the door of the production area serves as a barrier to cross pollution, the availability of procedures to prevent cross-contamination, rodent and pest control, and limit on the duration of storage of unpacked material. Based on the calculation of the gap using the fuzzy method, these activities have been very well done and obeyed by all human resources toward the CPOTB guidelines.

There is one question in the questionnaire which states that "The production area, storage area, and quality control area are used as a traffic lane for personnel not working in the area" with positive results on the gap calculation (Table 4). This activity is not in accordance with the guidelines of the CPOTB, where the CPOTB guides these areas only to be used for activities related to avoiding the risk of contamination from passerby. The production area, storage area, and quality control area should be protected from overexposure by improving ventilation and replacing machinery so that no dust or microorganisms enter the air. UKOT can use a respirator with High-Efficiency Particulate Water (HEPA) so that it can protect personnel, rooms, and products [15].

The initial material meets the specifications and is labeled before use and the data of receipt of the material listed on the container has been carried out in accordance with the CPOTB guidelines by personnel at UKOT. Personnel has carried out the batch numbering system at different processing and packaging stages (Table 5). A batch number is a designation consisting of numbers or letters or a combination of both, which is the identification of a batch, which allows a complete retrieval of the batch history, including all stages of production, control and distribution. From this understanding, labeling and recording of different batch numbers in the production process and packaging stage aim to facilitate the process of retelling the batch manufacturing history [2].

Cleaning materials and equipment have been separated from the processing room, flammable materials and chemicals have also been placed in certain areas and equipped with electrical equipment that is impervious to the explosion, and the quarantine area has become a restricted area (Table 5). Certain ingredients have dangerous reactive properties that can cause fire, explosion, burns, or blindness. Maintenance and management of tools and materials are very important to maintain the safety and security of work personnel. This is the reason that requires personnel to use face shields, gloves, and protective clothing to protect from exposure to hazardous materials [15].

Table 6 shows that the results of a positive gap calculation in the availability of written procedures detailing product recall in response to customer complaints and all decisions and actions taken as a result of complaints are recorded and reffered to related batch records, as well as evaluating the effectiveness of the implementation of a recall has been routinely carried out. Drug withdrawal is carried out to return the product with the same batch or entire product to the factory because of the detection of safety problems or defects of the product [16]. In the aspect of "Handling complaints for products, recalling products and returning products" in the СРОТВ, all complaints and information relating to the possibility of drug damage should be examined carefully in accordance with written procedures [2].

Disinfectants and detergents are stored in containers for a certain period of time and are always monitored for microbial contamination (Table 6). Disinfectants and detergents that will be used to clean and eliminate microorganism in the equipment used for the production process are very important to consider quality to reduce and minimize exposure to microorganisms that act as contaminants [17].

Risk management has been carried out properly in accordance with CPOTB, which is a systematic process for assessing, controlling, and assessing risk to the quality of a product, as well as evaluating the equivalence between the risk management process and the level of risk (Table 6). Quality risk management is a systematic process for evaluating, controlling, and assessing risk to the quality of a product [2]. All products and all processes have an element of risk. In the application of effective risk management, and organization needs to define 'risk' and must be agreed upon by the stakeholders in the UKOT [18].

The results of the calculation of positive gaps in the measurement dimensions are in calibration and checking the accuracy of the tools used to weigh, measure, check and record to support the production process of traditional medicines, as well as the consistency of data from the validation of results (Table 7). There is one question in Table 7 that has a positive value but does not comply with the rules in the CPOTB, namely the analysis method is not validated. In the CPOTB cited as "The method of analysis that was validated" [2]. The analysis method needs to be validated to prove that the method used is good and can guarantee the quality of traditional medicinal products, so this is a finding if the analysis method is not validated. 
Table 4. Milieu fuzzification

\begin{tabular}{|c|c|c|c|c|c|c|c|c|c|c|c|}
\hline \multirow{3}{*}{ Question } & \multicolumn{2}{|c|}{ Recap score } & \multicolumn{6}{|c|}{ Fuzzification } & \multirow{2}{*}{\multicolumn{3}{|c|}{ Defuzzification }} \\
\hline & \multirow{2}{*}{ Knowledge } & \multirow{2}{*}{ Practical } & \multicolumn{3}{|c|}{ Knowledge } & \multicolumn{3}{|c|}{ Practical } & & & \\
\hline & & & Low & Mid & High & Low & Mid & High & Knowledge & Practical & Gap \\
\hline Q20 & 24 & 24 & 2,0000 & 3,0000 & 4,0000 & 2,0000 & 3,0000 & 4,0000 & 3,5000 & 3,5000 & $0^{*}$ \\
\hline Q21 & 24 & 23 & 2,0000 & 3,0000 & 4,0000 & 1,9583 & 2,9375 & 3,9167 & 3,5000 & 3,4271 & $0,0729 * *$ \\
\hline Q22 & 13 & 11 & 1,5417 & 2,3125 & 3,0833 & 1,4583 & 2,1875 & 2,9167 & 2,6979 & 2,5521 & $0,1458^{* *}$ \\
\hline Q23 & 0 & 23 & 1,0000 & 1,5000 & 2,0000 & 1,9583 & 2,9375 & 3,9167 & 1,7500 & 3,4271 & $-1,6771$ \\
\hline Q24 & 24 & 23 & 2,0000 & 3,0000 & 4,0000 & 1,9583 & 2,9375 & 3,9167 & 3,5000 & 3,4271 & 0,07292 ** \\
\hline Q25 & 11 & 12 & 1,4583 & 2,1875 & 2,9167 & 1,5000 & 2,2500 & 3,0000 & 2,5521 & 2,625 & $-0,07292$ \\
\hline Q26 & 9 & 13 & 1,4167 & 2,1250 & 2,8333 & 1,5417 & 2,3125 & 3,0833 & 2,4792 & 2,6979 & $-0,2187$ \\
\hline Q27 & 24 & 24 & 2,0000 & 3,0000 & 4,0000 & 2,0000 & 3,0000 & 4,0000 & 3,5000 & 3,5000 & $0^{*}$ \\
\hline Q28 & 23 & 21 & 1,9583 & 2,9375 & 3,9167 & 1,8750 & 2,8125 & 3,7500 & 3,4271 & 3,2812 & $0,1458^{* *}$ \\
\hline Q29 & 23 & 22 & 1,9583 & 2,9375 & 3,9167 & 1,9167 & 2,8750 & 3,8333 & 3,4271 & 3,3542 & $0,0729 * *$ \\
\hline Q30 & 22 & 18 & 1,9167 & 2,8750 & 3,8333 & 1,7500 & 2,6250 & 3,5000 & 3,3542 & 3,0625 & 0,2917 ** \\
\hline
\end{tabular}

Notes: *The value of work practices is the same as the value of knowledge, **The value of work practice is higher than the value of knowledge

Table 5. Material fuzzification

\begin{tabular}{|c|c|c|c|c|c|c|c|c|c|c|c|}
\hline \multirow{3}{*}{ Question } & \multicolumn{2}{|c|}{ Recap score } & \multicolumn{6}{|c|}{ Fuzzification } & \multirow{2}{*}{\multicolumn{3}{|c|}{ Defuzzification }} \\
\hline & \multirow{2}{*}{ Knowledge } & \multirow{2}{*}{ Practical } & \multicolumn{3}{|c|}{ Knowledge } & \multicolumn{3}{|c|}{ Practical } & & & \\
\hline & & & Low & Mid & High & Low & Mid & High & Knowledge & Practical & Gap \\
\hline Q31 & 24 & 22 & 2,0000 & 3,0000 & 4,0000 & 1,9167 & 2,8750 & 3,8333 & 3,5000 & 3,3542 & $0,1458^{* *}$ \\
\hline Q32 & 12 & 13 & 1,5000 & 2,2500 & 3,0000 & 1,5417 & 2,3125 & 3,0833 & 2,6250 & 2,6979 & $-0,0729$ \\
\hline Q33 & 24 & 21 & 2,0000 & 3,0000 & 4,0000 & 1,875 & 2,8125 & 3,7500 & 3,5000 & 3,2812 & $0,2187^{* *}$ \\
\hline Q34 & 23 & 24 & 1,9583 & 2,9375 & 3,9167 & 2,0000 & 3,0000 & 4,0000 & 3,4271 & 3,5000 & $-0,0729$ \\
\hline Q35 & 23 & 22 & 1,9583 & 2,9375 & 3,9167 & 1,9167 & 2,8750 & 3,8333 & 3,4271 & 3,3542 & $0,0729 * *$ \\
\hline Q36 & 23 & 20 & 1,9583 & 2,9375 & 3,9167 & 1,8333 & 2,7500 & 3,6667 & 3,4271 & 3,2083 & $0,2187^{* *}$ \\
\hline Q37 & 4 & 20 & 1,1667 & 1,7500 & 2,3333 & 1,8333 & 2,7500 & 3,6667 & 2,0417 & 3,2083 & $-1,1667$ \\
\hline Q38 & 24 & 23 & 2,0000 & 3,0000 & 4,0000 & 1,9583 & 2,9375 & 3,9167 & 3,5000 & 3,4271 & $0,0729 * *$ \\
\hline Q39 & 23 & 22 & 1,9583 & 2,9375 & 3,9167 & 1,9167 & 2,8750 & 3,8333 & 3,4271 & 3,3542 & $0,0729 * *$ \\
\hline Q40 & 2 & 21 & 1,0833 & 1,6250 & 2,1667 & 1,8750 & 2,8125 & 3,7500 & 1,8958 & 3,2812 & $-1,3854$ \\
\hline
\end{tabular}

Notes: *The value of work practices is the same as the value of knowledge, ** The value of work practice is higher than the value of knowledge 
Table 6. Method fuzzification

\begin{tabular}{|c|c|c|c|c|c|c|c|c|c|c|c|}
\hline \multirow{3}{*}{ Question } & \multicolumn{2}{|c|}{ Recap score } & \multicolumn{6}{|c|}{ Fuzzification } & \multirow{2}{*}{\multicolumn{3}{|c|}{ Defuzzification }} \\
\hline & \multirow{2}{*}{ Knowledge } & \multirow{2}{*}{ Practical } & \multicolumn{3}{|c|}{ Knowledge } & \multicolumn{3}{|c|}{ Practical } & & & \\
\hline & & & Low & Mid & High & Low & Mid & High & Knowledge & Practical & Gap \\
\hline Q41 & 24 & 22 & 2,0000 & 3,000 & 4,0000 & 1,9167 & 2,8750 & 3,8333 & 3,5000 & 3,3542 & $0,1458^{* *}$ \\
\hline Q42 & 6 & 17 & 1,2500 & 1,8750 & 2,500 & 1,7083 & 2,5625 & 3,4167 & 2,1875 & 2,9896 & $-0,8021$ \\
\hline Q43 & 23 & 22 & 1,9583 & 2,9375 & 3,9167 & 1,9167 & 2,8750 & 3,8333 & 3,4271 & 3,3542 & $0,0729 * *$ \\
\hline Q44 & 24 & 22 & 2,0000 & 3,0000 & 4,0000 & 1,9167 & 2,8750 & 3,8333 & 3,5000 & 3,3542 & $0,1458^{* *}$ \\
\hline Q45 & 24 & 22 & 2,0000 & 3,0000 & 4,0000 & 1,9167 & 2,8750 & 3,8333 & 3,5000 & 3,3542 & $0,1458^{* *}$ \\
\hline Q46 & 7 & 19 & 1,2917 & 1,9375 & 2,5833 & 1,7917 & 2,6875 & 3,5833 & 2,2604 & 3,1354 & $-0,875$ \\
\hline Q47 & 23 & 23 & 1,9583 & 2,9375 & 3,9167 & 1,9583 & 2,9375 & 3,9167 & 3,4271 & 3,4271 & $0^{*}$ \\
\hline Q48 & 12 & 11 & 1,5000 & 2,2500 & 3,0000 & 1,5417 & 2,3125 & 3,0833 & 2,6250 & 2,6979 & $-0,0729$ \\
\hline Q49 & 21 & 20 & 1,8750 & 2,8125 & 3,7500 & 1,8333 & 2,7500 & 3,6667 & 3,2812 & 3,2083 & $0,0729 * *$ \\
\hline Q50 & 23 & 21 & 1,9583 & 2,9375 & 3,9167 & 1,8750 & 2,8125 & 3,7500 & 3,4271 & 3,2812 & $0,1458^{* *}$ \\
\hline Q51 & 24 & 22 & 2,0000 & 3,0000 & 4,0000 & 1,9167 & 2,8750 & 3,8333 & 3,5000 & 3,3542 & $0,1458^{* *}$ \\
\hline Q52 & 22 & 21 & 1,9167 & 2,875 & 3,8333 & 1,8750 & 2,8125 & 3,7500 & 3,3542 & 3,2812 & $0,0729 * *$ \\
\hline
\end{tabular}

Notes: *The value of work practices is the same as the value of knowledge, **The value of work practice is higher than the value of knowledge

Table 7. Measurement fuzzification

\begin{tabular}{|c|c|c|c|c|c|c|c|c|c|c|c|}
\hline \multirow{3}{*}{ Question } & \multicolumn{2}{|c|}{ Recap score } & \multicolumn{6}{|c|}{ Fuzzification } & \multirow{2}{*}{\multicolumn{3}{|c|}{ Defuzzification }} \\
\hline & \multirow{2}{*}{ Knowledge } & \multirow{2}{*}{ Practical } & \multicolumn{3}{|c|}{ Knowledge } & \multicolumn{3}{|c|}{ Practical } & & & \\
\hline & & & Low & Mid & High & Low & Mid & High & Knowledge & Practical & Gap \\
\hline Q53 & 24 & 21 & 2,0000 & 3,0000 & 4,0000 & 1,8750 & 2,8125 & 3,7500 & 3,5000 & 3,2812 & $0,2187 * *$ \\
\hline Q54 & 13 & 10 & 1,5417 & 2,3125 & 3,0833 & 1,4167 & 2,1250 & 2,8333 & 2,6979 & 2,4792 & $0,2187^{* *}$ \\
\hline Q55 & 24 & 21 & 2,0000 & 3,0000 & 4,0000 & 1,8750 & 2,8125 & 3,7500 & 3,5000 & 3,2812 & $0,2187 * *$ \\
\hline Q56 & 1 & 22 & 1,0417 & 1,5625 & 2,0833 & 1,9167 & 2,8750 & 3,8333 & 1,8229 & 3,3542 & $-1,5312$ \\
\hline Q57 & 24 & 20 & 2,0000 & 3,0000 & 4,0000 & 1,8333 & 2,7500 & 3,6667 & 3,5000 & 3,2083 & $0,2917 * *$ \\
\hline Q58 & 24 & 24 & 2,0000 & 3,0000 & 4,0000 & 2,0000 & 3,0000 & 4,0000 & 3,5000 & 3,5000 & $0 *$ \\
\hline Q59 & 22 & 19 & 1,9167 & 2,875 & 3,8333 & 1,7917 & 2,6875 & 3,5833 & 3,3542 & 3,1354 & $0,2187 * *$ \\
\hline Q60 & 6 & 17 & 1,2500 & 1,875 & 2,5000 & 1,7083 & 2,5625 & 3,4167 & 2,1875 & 2,9896 & $-0,8021$ \\
\hline
\end{tabular}

Notes: *The value of work practices is the same as the value of knowledge, ** The value of work practice is higher than the value of knowledge 
Table 8. The results of the six-category gap

\begin{tabular}{ccc}
\hline Elements & Gap Summary & Rank \\
\hline Manpower & $-0,9479$ & 2 \\
Machinery & $0,1146^{* *}$ & 1 \\
Milieu & $-1,1667$ & 4 \\
Material & $-1,8958$ & 6 \\
Method & $-0,8021$ & 3 \\
Measurement & $-1,1667$ & 5 \\
\hline
\end{tabular}

Notes: ${ }^{* *}$ The value of work practice is higher than the value of knowledge

The control has been well done by the personnel at UKOT by monitoring water, microbiologists, and air pollution regularly which is shown in Table 7. Table 7 also shows that self-inspection has been carried out at least once a year at UKOT and in accordance with CPOTB. The purpose of self-inspection is to evaluate all aspects of production that are designed to detect weakness in the implementation of the CPOTB and to determine the necessary corrective actions. Self-inspection can be done per section in accordance with company needs and the frequency of self-inspection should be written in a fixed procedure $[2]$.

After calculating the gap in each category, from Table 8 it can be seen that only the categories of the machinery have positive results. From these data, it can be seen that not all human resources fulfill work conformity with CPOTB. The gaps between each elements are shows significant differences as it is according to how fuzzy logic measurement supposed to. However, this method is somehow needs a pretty long iterations only in order to calculate the gaps. Further research needs to perform a shorter and precise calculation of modified fuzzy logic or other method.

\section{Conclusion}

The result has proven that fuzzy logic able to calculate the gaps between human resource knowledge and practice. There is finding in the calculation of gaps from the milieu category that personnel can walk through the production area, storage area, and quality control area and in the measurement category where analysis of methods for maintaining drug quality has not been validated periodically. These results are not in accordance with the rules in CPOTB. Based on the calculation of the gap of the six categories to assess work conformity at UKOT Yogyakarta, the only positive category is machinery. Thus the human resources that have implemented the guidelines in work practices at UKOT Yogyakarta well are from the category of machinery.

\section{Acknowledgement}

The author thanks Mr. apt. Asyifuddin, S.Farm and all parties who have helped so that this research can be completed.

\section{References}

[1] Yusuf Priyandari, Azmi Mas'ud, and Y. Prasetyo., "Implementasi Validasi dan Kualifikasi sebagai Salah Satu Metode Penjaminan Mutu di PT. XYZ," in Seminar Internasional dan Konferensi Nasional IDEC, Surakarta, 2016.

[2] BPOM, "Persyaratan teknis cara pembuatan obat tradisional yang baik," B. P. O. d. M. R. Indonesia, ed., Badan Pengawas Obat dan Makanan Republik Indonesia, 2011.

[3] Ninuk Purnaningsih, Titi Mawasti, and T. Saraswati, "Analisis kebutuhan pendampingan dan kompetensi pendampingan usaha industri jamu," Jurnal Jamu Indonesia, vol. 2, no. 2, pp. 68-85, 2017.

[4] M. Crnogorac, M. Tanasijević, D. Danilović et al., "Selection of Artificial Lift Methods: A Brief Review and New Model Based on Fuzzy Logic," Energies, vol. 13, no. 7, pp. 1758, 2020.

[5] Jeffrey E. Jeffrey, and J. S. Plouffe, "The Fuzzy Logic Method for Simpler Forecasting," Intech, vol. 3, no. 3, pp. 25-52, 2011.

[6] Mukaidono, and Masao, Fuzzy Logic for Beginners: World Scientific Publishing Co, 2002. 
[7] M. Pislaru, I. V. Herghiligiu, and I.-B. Robu, "Corporate sustainable performance assessment based on fuzzy logic," Journal of Cleaner Production, vol. 223, pp. 998-1013, 2019.

[8] A. Hosseinzadeh, A. Yektadoost, H. Hozouri et al., "Quality assurance status in iranian pharmaceutical industry: A survey," Journal of Pharmacoeconomics and Pharmaceutical Management, vol. 1, no. 1, pp. 14-21, 2015.

[9] Kusumadewi Sri, and H. S., Neuro fuzzy: Integrasi sistem fuzzy dan jaringan syaraf, 2 ed., Yogyakarta: Graha Ilmu, 2010.

[10] N. M. Stefano, N. C. Filho, R. Barichello et al., "A Fuzzy SERVQUAL Based Method for Evaluated of Service Quality in the Hotel Industry," Procedia CIRP, vol. 30, pp. 433-438, 2015.

[11] R. Liu, L. Cui, G. Zeng et al., "Applying the fuzzy SERVQUAL method to measure the service quality in certification \& inspection industry," Applied Soft Computing, vol. 26, pp. 508-512, 2015.

[12] Jafar Babapour, Arian Gholipour, and G. Mehralian, "Human Resource Management Challenges to Develop Pharmaceutical Industry: Evidence from Developing Countries," Iranian Journal of Pharmaceutical Research, vol. 17, no. 2, pp. 224-238, 2018.

[13] Pomkul Suksod, and C. Cruthaka, "The Effects of Human Resource Practices on Employee Organizational Commitment: Findings from the Pharmaceutical Industry in Thailand," Sys Rev Pharm, vol. 11, no. 3, pp. 77-86, 2020.

[14] Bundit Pungnirund, Nattapong Techarattanased, and G. Mutakalin, "The Effects of Human Resource Practices on Perceived Organizational Support and Job Satisfaction in Pharmacy Industry of Bangkok City in Thailand," A multifaceted review journal in the field of pharmacy, vol. 11, no. 1, pp. 506-514, 2020.

[15] Debjit Bhowmik, S. Durai Vel, Rajalakshmi A.N et al., "Recent Trends in Hazards in the Pharmaceutical Industry and Safety Precaution," Elixir Pharmacy, vol. 69, 2014.

[16] Abhinaya N, Girish Thunga, Muddukrishna BS et al., "A Research on Effective Management of Manufacturing Defects to Avoid Product Recalls: A Challenge to Pharmaceutical Industry," Research Journal of Pharmacy and Technology, vol. 12, no. 12, 2019.

[17] X. Wang, O. A. Young, and D. P. Karl, "Evaluation of cleaning procedures for allergen control in a food industry environment," J Food Sci, vol. 75, no. 9, pp. T149-55, Nov-Dec, 2010.

[18] R. M. Haleem, M. Y. Salem, F. A. Fatahallah et al., "Quality in the pharmaceutical industry - A literature review," Saudi Pharm J, vol. 23, no. 5, pp. 463-9, Oct, 2015. 